\title{
Letter from Brasilia
}

\section{Yellow fever}

\author{
P D Marsden
}

Salvador was the first capital of Brazil, and it was to this city that the Portuguese royal family fled from the threat of Napoleon, shepherded by the British navy. In exchange the British were awarded certain trading rights with Portugal's richest colony, and still today you can see evidence of this in big things, such as the railways and telephones, and in small things, such as the old domestic ceramics. We are together in Salvador standing in front of the iron gate of the English cemetery. I have rung the bell, and we are let in without comment as, because of my interest in gravestone legends, I am one of their most frequent visitors. I have a large collection of legends from all over the world, although West Africa (the white man's grave) is my richest source. My favourite is one from a London churchyard stating that a prominent social figure of the time died of a rupture of a blood vessel in his chest, which labels him as syphilitic even in death. In the graveyard in Salvador I show you the legend of a 19 year old seaman from Liverpool who died of yellow jack. There are several other gravestones that mention yellow fever.

I want to show you a plaque on the wall on the right hand side of the gate. It reads "Sacred to the memory of the English gentlemen who died of yellow fever during the construction of the Bahia and São Francisco railway and who are buried at Montserrat. This tablet has been erected by public subscription 1800." Many workers died of malaria and yellow fever executing such public works in the tropics, the most famous in Brazil being the Madeira Mamoré railroad.

Yellow fever still kills people in Brazil, and near Brasília in 1973 there was an epidemic. In jungle yellow fever transmission is effected by mosquitoes, which feed off monkey reservoirs and then carry the arbovirus to man. The forest vectors, haemagogus mosquitoes, have a beautiful blue green metallic body. Most monkeys in Equatorial Africa and America have antibodies to the virus. A colleague who shot many monkeys in The Gambia made this observation. Virus transmission goes on among the monkey colony in the tree tops with some deaths occurring, although like humans many are mildly affected.

The problem arises when people enter this environment and destroy it or when other mosquitoes with a wider range of habitat enter the transmission cycle. For instance in Africa Aedes africanus mosquitoes maintain the cycle in the monkey colony but Aedes simpsoni can transfer the virus to humans on the edge of the forest, and if infected individuals enter towns and Aedes aegypti is present then urban yellow fever may start. This is the great fear with yellow fever, an urban epidemic in which $A$ aegypti transmits infection among humans. Shipboard yellow fever is usually transmitted by this mosquito so it probably introduced the virus to the young Liverpudlian seaman. Urban yellow fever has caused terrible loss of life in cities of the New World and Africa, although no such epidemic has been recorded in Brazil since 1942.

Hospitals receiving patients from endemic areas must pay particular attention to patients with a diagnosis of infectious hepatitis: most will be infected with the hepatitis viruses, but the possibility of yellow fever always exists. Sometimes in severe cases the

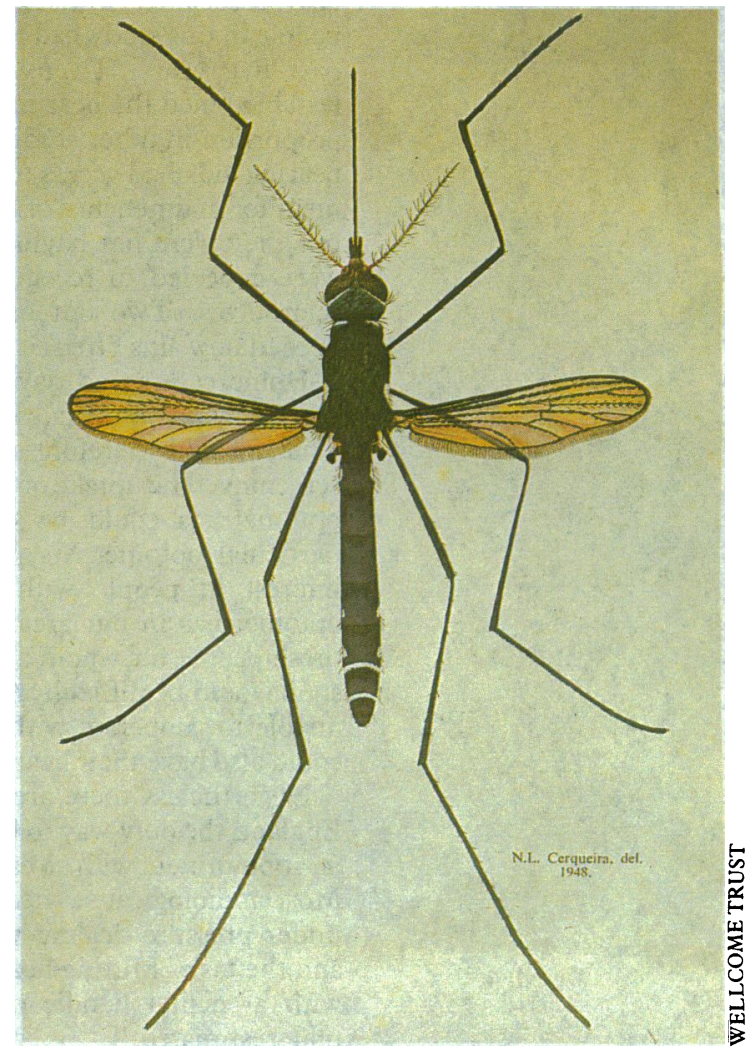

Haemogogus spegazzinii, the forest vector for yellow fever

doctor is alerted by mental confusion (coma vigil), Faget's sign, a tendency to bleeding, or the degree of renal disease, but proof comes from liver biopsy. Therefore, in cases of jaundice with fever if patients have normal bleeding and clotting times a liver biopsy should be done, and in all fatal cases liver histology should be carefully examined. In yellow fever there is mid-zonal necrosis of the lobule and inclusion bodies (councilman bodies). If this is found then the yellow fever vigilance team of the ministry of health should be informed of the patient's address, and trained field workers will be sent to survey the area. We encountered yellow fever in a woman who had visited a park 150 kilometres from Brasília. Prevention is the key as there is no specific treatment for yellow fever.

Recently a lorry driver died in São Paulo of yellow fever, but he had driven the length of Brazil from Amazonas so the origin of his infection was difficult to establish. A worrying aspect of the current Brazilian position is the reinvasion by $A$ aegypti of cities such as Rio de Janeiro and Fortaleza. This vector of urban yellow fever is difficult to control and poses a threat of transmitting not only yellow fever but dengue. Dengue is usually self limiting and non-fatal, but a haemorrhagic syndrome associated with it is often fatal, though this is reported mainly in Cuba and the Orient. So there are two good reasons for controlling A aegypti. In 1955 Brazil declared its territory free of this mosquito, but the mosquito travels well and has reinvaded parts of Brazil. It breeds in small bodies of water such as a plant pot in the garden or rainwater in 
car tyres. With a sophisticated population like that in Rio de Janeiro television will persuade most viewers to inspect their gardens and help the public health authorities, but this has varying success in the interior. For example, in Roraima state in 198210000 cases of yellow fever occurred in a few months. To make matters worse in terms of control a second species with similar breeding habits has been recorded in Brazil, a known dengue vector Aedes albopictus. This species has been recorded in the states of Rio de Janeiro, Espírito Santo, Minas Gerais, Rio Grande do Norte, and São Paulo.

James Porterfield wrote about research into yellow fever in West Africa in the 1989 Christmas issue of the $B M$ f. In 1959 I worked in the laboratory in which Stokes caught fatal yellow fever in Yaba Lagos. The Rockefeller Foundation assault on yellow fever cost the lives of six scientists but led to an understanding of American jungle yellow fever and the development of the 17D vaccine-one of the two most effective vaccines known. Brazil provides millions of doses annually, all made at the Instituto Oswaldo Cruz, Rio de Janeiro. Naturally some failures occur at the end of the line as in any national programme. Witness me stumbling from a bus at 4 am coming back from the field. In my old clothes and with a beard I am thought to be a hippy estrangeiro. In vain I protest that I am the professor of medicine in Brasília and have been vaccinated. I have no document because I always lose them. The health inspector orders that I receive my seventh dose of yellow fever vaccine (and one lasts 10 years). And the health inspector at Porto Velho airport gives 2-3 doses of vaccine a day on request but opens a 20 dose ampoule that then has to be discarded. It is expensive so why can't we have it in smaller ampoules? Tourist agencies and airport authorities are efficient on vaccine prophylaxis against yellow fever, but some get through.

I'd like to close as I started, with the old port of Salvador. Sometimes, in a time of peace in the old days a big square rig sailing ship would drift in with no one alive on board. The explanation could be several infectious diseases such as malaria, plague, cholera, and typhus but could also be yellow fever. In the nineteenth century nobody paid any attention to $A$ aegypti breeding in the scuppers.

\section{NHS Review}

\section{Kenneth Clarke: hatchet man or remoulder?}

\section{John Roberts}

Fohn Roberts is an American journalist turned internist and epidemiologist. He spent two months with us in the autumn burrowing into the depths of the NHS. We will be publishing a series of articles from him on his impressions, and we begin with an interview with Kenneth Clarke, who at the time of the interview was Secretary of State for Health. He and the Prime Minister have since moved on, but there are no signs that the path on which MrClarke set out has changed.

JR: What prompted the government to write the white paper?

Kc: We believed that if the health service is to carry on giving free treatment at high - clinical standards, reasonably accessible to everybody, we had to improve the way the health service was run - as well as put more resources into it. Also, it is a giant bureaucratic organisation set up on an overcentralised model. It needed modern management and better methods of distributing money. It needed to introduce measures of the effectiveness of health care-some means of judging what we're getting for our money and what we can buy as we put more resources in.

JR: How can one judge effectiveness in something so nebulous as "care"?

KC: No health system in the world measures outcomes. It's not regarded as the subject matter of political debate. We're changing that, of course. Clinical audit obviously is going to be a method of assessing effectiveness. The contract system - whereby people purchase care from providers of care-will get the purchasers to stipulate what they want and to stipulate the quality of what they get - that is, measure performance against what they've asked for.

British Medical Journal, London WC1H 9JR John Roberts, MD

BrMed F 1990;301:1383-6
JR: What's to keep expenses here from going the way of those in the United States?

KC: The BMA had this crazy idea that we were bringing American health care to Britain. I can't see much resemblance between what we're proposing and the

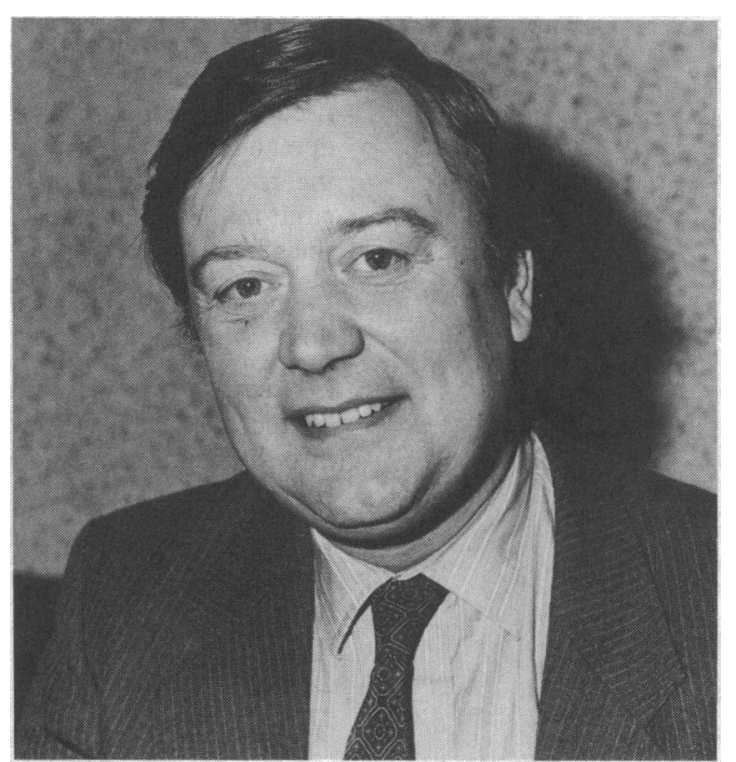

unfortunate state of affairs that exists in the United States. My opponents said we were privatising, going over to American type private health care. We're not. I'm opposed to that.

\section{Consumer demand and the role of the GP}

JR: What's to keep hospitals from marketing for certain diseases?

Kc: There's no such thing as a "more profitable disease" in the NHS. They won't be allowed to accumulate true profits. They will respond to what health authorities and general practitioner purchasers want to buy. And the fastest growing services I predict are things like geriatric services. If you look at the demography of this country, that's the fastest growing group. High tech surgery won't be profitable.

It is only in an insurance system where it is possible to market particularly high technology, which the 